\title{
EFFECT OF FEEDING OF CHELATED ZINC FORM ON SECURITY, PRODUCTIVITY AND SLAUGHTER PARAMETERS OF BROILERS
}

\author{
Tetiana Fotina \\ Department of Veterinary Examination, Microbiology, \\ Zoohygiene and Safety and Quality of Livestock Products \\ tif_ua@meta.ua \\ Hanna Fotina \\ Department of Veterinary Examination, Microbiology, \\ Zoohygiene and Safety and Quality of Livestock Products \\ super.annafotina@ukr.net \\ Svitlana Nazarenko \\ Department of Veterinary Examination, Microbiology, \\ Zoohygiene and Safety and Quality of Livestock Products ${ }^{I}$ \\ nazarenko.sveta2014@gmail.com \\ Roman Tymoshenko \\ Department of Veterinary Examination, Microbiology, \\ Zoohygiene and Safety and Quality of Livestock Products ${ }^{1}$ \\ roman.tymoshenko1980@gmail.com \\ Oleksii Fotin \\ Department of Veterinary Examination, Microbiology, \\ Zoohygiene and Safety and Quality of Livestock Products \\ alexeyfotin79@gmail.com \\ ${ }^{1}$ Sumy National Agrarian University \\ 160 Herasyma Kondratieva str., Sumy, Ukraine, 40021
}

\begin{abstract}
The results of the effect of feeding the chelated form of Zinc on the safety, productivity and slaughter parameters of broiler chickens are presented.

The aim of this study was to determine the safety, productivity and slaughter parameters of broilers on the background of feeding chelated form of Zinc.

Materials and methods. Experimental studies were conducted during 2020 on broiler chickens cross Cobb-500 in the vivarium of the Veterinary Faculty of Sumy National Agrarian University (Ukraine), divided into two groups on the principle of analogues (control and experimental) of 50 broilers each. The source of zinc for chickens in the control group was their sulfates. Chelated forms of Zinc were used for broiler chickens of the experimental group. All groups of broiler chickens were administered the compound with compound feed in a dose that corresponded to the daily requirement of the bird in this trace element. The duration of the experiment is 42 days. The growth and development of broilers were evaluated on the basis of determining the relevant zootechnical indicators. Live weight of birds was determined by individual weighing on scales of the VNC type with an accuracy of $\pm 1 \mathrm{~g}$ at the age of 7, 14, 21, 28, 35 and 42 days. Both scientific and economic experiments also determined the preservation of livestock - daily by the number of culled and dead birds. Feed consumption was recorded daily, for each week of cultivation and for the entire period of the experiment. At the end of the experiment, the cost of feed per $1 \mathrm{~kg}$ of live gained weight was calculated.

Results. According to the results of the conducted researches, it was established that feeding of the chelated form of Zinc probably increased both the average daily gain and the total live weight of broiler chickens at different age periods of rearing. The live weight of chickens at the beginning of the experiment was almost the same, but at 7 days of age it tended to increase in chickens of the experimental group, although a significant difference between groups in this indicator was not found. It was found that the weight of uneviscerated, semi-eviscerated and eviscerated chicken in poultry of the experimental group was greater than similar indicators in the young animals of the control group by $9.3,9.2$, and $9.8 \%$, and this difference was significant $(p<0.01)$. The yield of semi-eviscerated carcasses was higher in ones of the experimental group (84.19\%), and the difference was significant $(p<0.05)$.
\end{abstract}


Conclusions. It was found that the live weight of chickens of the experimental group (consumption of feed with a chelated form of Zinc) prevailed at 7 days of age by $1.1 \mathrm{~g}$; on the 14th day - on $22.1 \mathrm{~g}(p<0.01)$; at 21 days - $35.4 \mathrm{~g}(p<0.01)$; at 28 days $94.5 \mathrm{~g}(p<0.05)$; at 35 days - $133.6 \mathrm{~g}(p<0.01)$; at 42 days - at $218.9 \mathrm{~g}(p<0.05)$. Preservation of young animals in the experimental group, which used chelated compounds of Zinc, was higher and amounted to $96 \%$, compared with the control $-92 \%$. By age, feed costs per unit weight gain were lower in the experiment, respectively: $0.05 ; 0.08 ; 0.12 ; 0.06 ; 0.07$ and $0.05 \mathrm{~kg}$, compared to the control group. Growing broiler chickens on compound feed with a chelated form of Zinc by $9.8 \%(p<0.01)$ increases the weight of the eviscerated carcass.

Keywords: slaughter rates, live weight, broiler chickens, zinc chelated forms, Cobb-500 cross, veterinary examination.

DOI: $10.21303 / 2504-5679.2021 .001856$

\section{Introduction}

It is well known that chemical elements are required for the normal development of animals and birds. There are macro- and micronutrients. Macronutrients include carbon, nitrogen, as well as phosphorus and calcium, which are used to build bones and eggshells. Trace elements are chemical elements that are involved in metabolism in extremely small quantities. These are iron, copper, zinc, manganese, magnesium, cobalt, molybdenum, selenium. Therefore, quality feed should contain a sufficient amount of both macronutrients and micronutrients.

Usually microelements in the form of inorganic salts - sulfates and chlorides are used in feeds. Such salts are easily soluble and technological for mixing. However, their biological action is complicated by the phenomenon of chemical antagonism of metals. For example, iron is a chemical antagonist of zinc, and zinc is a chemical antagonist of copper. Being in a dissociated, easily soluble state, metal ions are able to react with other chemicals that enter the intestine with food and form a thick mixture called chyme. There is also the possibility of chemical reactions, as a result of which trace elements form insoluble compounds and precipitate, as a result of which they cannot be used in metabolic processes. These problems are solved by using chelates-compounds of trace elements with organic substances, for example, with amino acids [1].

The chemical bond of a metal atom to a ligand is usually quite strong, which determines the stability of the chelate molecules.

This does not cause the phenomenon of metal antagonism, and in addition, amino acid ligands give chelates the ability to more easily pass through cell membranes to be directly involved in metabolic processes. It is very important that trace elements in the form of chelates have excellent thermal stability, so they can be used for the production of both bulk and granular feed [2].

Recently, nanotechnology is widely used as a new direction in many industries. Nanoparticles have the potential for efficient delivery of essential trace elements in animal feed, while the potential increases the bioavailability of minerals. This improved availability can be explained by both the small size and large ratio of surface to volume of these particles. The inclusion of a functionalized coating, such as an amino acid, can improve the stability of nanoparticles in solution and promote their assimilation. Zinc is an important trace element for all living species. In its dominant degree of oxidation, zinc (II) is an integral part of a number of biochemical pathways as a catalytic or regulatory cofactor, and also has a structural role in many other functional proteins. Therefore, zinc is necessary for normal growth and maintenance, repair of damaged tissues and is vital for the development of bones and feathers [3].

Many researchers have added $\mathrm{Zn}$ in inorganic or organic form to broilers and observed improvements in growth rates [4]; but others have not seen the effect of inorganic or organic Zn sources on growth efficiency [5]. Poultry is one of the most important foods. It has great energy and biological values, a high level of digestibility and has characteristic taste properties [6]. The nutritional value of poultry meat is due to its ability to chemically match the formula of a balanced diet in terms of protein, fat and carbohydrates. The biological value of meat is due to the composition and properties of its protein components and the degree of assimilation of nitrogenous substances by the human body [7].

Currently, in the feeding of poultry is often a deficiency of many minerals and biologically active substances. The use of inorganic trace elements to enrich diets is not effective enough, and this leads to overconsumption of feed. To supplement the deficiency of micronutrients in feed, their inorganic derivatives are traditionally used, the bioavailability of which in many cases is low [8]. 
To date, in Ukraine there are no created mineral premixes that contain chelated compounds of trace elements and no recipes have been developed for compound feeds with their addition to animals. Therefore, proper and rational feeding of animals with good quality feed, which is balanced in nutritional and energy value, contains a sufficient amount of biologically active substances - a necessary condition for achieving high poultry productivity, quality and safety of livestock products [9].

It is possible to increase the bioavailability of microelements for animals due to the use of chelated compounds in feeding [10]. Getting with the feed into the gastrointestinal tract of birds, chelated compounds of trace elements are absorbed in the body in the form of protein chelates of divalent metals with hydrolysates of proteins and amino acids, which easily penetrate the intestinal wall [11]. The introduction of intensive technologies for the production of poultry products, including broiler chickens, involves the use of a significant number of nutraceuticals, including vitamins, probiotics, prebiotics, macro-and micronutrients [12].

The use of feed additives «Bioplex Zinc» and «Bioplex Copper», based on organic chelating compounds of Zinc, Copper and proteins, improves the absorption, metabolism of feed nutrients, increases the hemoglobin content, the concentration of total protein in the serum, increase the productivity and safety of broiler chickens and has a positive effect on the quality of meat [13].

The role of zinc in animals is that it is a necessary component or activator of many enzymes and hormones, affects the metabolism of proteins, fats and carbohydrates, strengthens the immune system, affects the hatchability of broiler chickens [14]. Zinc deficiency in the body of broiler chickens leads primarily to disorders in protein synthesis, resulting in inhibited growth and increased rearing time [15].

Prolonged zinc deficiency in the feed of the parent flock of poultry leads to a decrease of its level in blood plasma, bone tissue, pancreas, liver, kidneys [16]. This reduces the activity of phosphatase in blood plasma, bones and duodenum, blood carbonic anhydrase, carboxypeptidase A and B of the pancreas, lactate dehydrogenase of the heart, skeletal muscle, kidney, alcohol dehydrogenase of the testes [17]. Ultimately, this leads to reduced hatchability due to poor fertilization of eggs [18].

Zinc is a structural component or required for the catalytic activity of more than 200 metalloenzymes involved in various metabolic processes: DNA and RNA polymerases, dehydrogenases, carboxypeptidases, phosphatases, superoxide dismutases, alcohol dehydrogenases, pyruvate carboxylases and others [19].

Currently, the search for safe premixes to stimulate the growth of poultry, increase the slaughter yield of carcasses [20]. But in modern conditions it is not enough just to take into account the increase in poultry productivity, it is also necessary to pay attention to product quality [21].

The aim of this study was to determine the safety, productivity and slaughter parameters of broiler chickens on the background of feeding chelated form of Zinc.

\section{Materials and methods}

Experimental studies were conducted during 2020 on broiler chickens cross Cobb-500 in the vivarium of the Veterinary Faculty of Sumy National Agrarian University (Ukraine), divided into two groups on the principle of analogues (control and experimental) of 50 broilers each.

All animal studies were performed in accordance with Directive 2010/63/EU as amended by Regulation (EC) 2019/1010 and approved by the conclusion of the Commission on Ethics and Bioethics of the Faculty of Veterinary Medicine of Sumy National Agrarian University Protocol No. 3 dated 21.12.2020.

The source of zinc for chickens in the control group was its sulfates. Chelated forms of Zinc were used for broiler chickens of the experimental group. All groups of broiler chickens were administered the compound with compound feed in a dose that corresponded to the daily requirement of the bird in this trace element. The duration of the experiment is 42 days. The growth and development of broiler chickens were evaluated on the basis of determining the relevant zootechnical indicators. Live weight of birds was determined by individual weighing on scales of the VNC type with an accuracy of $\pm 1 \mathrm{~g}$ at the age of 7,14,21,28, 35 and 42 days. Both scientific and economic experiments also determined the preservation of livestock - daily by the number of culled and dead birds. 
Feed consumption was recorded daily, for each week of cultivation and for the entire period of the experiment. At the end of the experiment, the cost of feed per $1 \mathrm{~kg}$ of live weight gain was calculated.

The assessment of the pre-slaughter condition and veterinary-sanitary examination of the products of slaughter of broiler chickens was carried out in accordance with the «Rules of pre-slaughter veterinary inspection of animals and veterinary-sanitary examination of meat and meat products».

At the same time, observed the behaviour of birds, paid attention to the condition of plumage and available mucous membranes, the presence of secretions from the eyes and cloaca, the condition and color of the beak, crest, limbs, the nature of manure, respiration, determined body temperature. Feeding of broiler chickens was normalized according to the bird's need for energy, nutrients and biologically active substances. Access to poultry feed and water was free. Before slaughter, the bird was kept for 10 hours without food with free access to water. Access to water was restricted 3 hours before slaughter. The microclimate in the room was regulated automatically.

Bleeding of the birds was carried out by cutting the vessels of the neck, after which the carcasses were eviscerated with water at a temperature of $51 . .57^{\circ} \mathrm{C}$ for two minutes, the plumage was removed manually. Then the carcasses were eviscerated according to the generally accepted method [7].

Slaughter rates of broiler chickens (weight of non-eviscerated, semi-eviscerated, eviscerated carcasses, weight of edible internal organs, as well as slaughter yield) were determined according to the method [4].

The obtained digital indicators were processed by variational-statistical methods. Determined the arithmetic mean $(M)$, the statistical error of the arithmetic mean $(m)$. The probability of the difference between the arithmetic mean of the two variation series was determined by the criterion of reliability $(t d)$ and by Student's tables. The difference between the two values was considered probable at * $-p \leq 0.05 ; * *-p \leq 0.01 ; * * *-p \leq 0,001$.

\section{Results}

The average daily consumption of feed by poultry of the experimental groups, on average per 1 broiler, is given in Table 1.

Table 1

Indicators of average daily consumption of feed by broiler chickens, $\mathrm{g}$

\begin{tabular}{ccc}
\hline \multirow{2}{*}{ Age of broilers, days } & \multicolumn{2}{c}{ Groups } \\
\cline { 2 - 3 } & control & study \\
\hline $1-7$ & 22.2 & 23.5 \\
\hline-14 & 60.6 & 61.2 \\
$15-21$ & 117.2 & 122.4 \\
$22-28$ & 130.2 & 131.4 \\
$29-35$ & 144.4 & 146.2 \\
$36-42$ & 150.5 & 161.4
\end{tabular}

Analyzing the data in Table 1, the largest amount of feed was consumed by broiler chickens of the experimental group, to which compound feed was added chelated forms of Zinc.

Such indicators were observed throughout the experiment, but we did not find a significant difference between the groups on this indicator.

In the next stage of the study, we determined the live weight of broiler chickens at the daily age of the control and experimental groups. There was no significant difference. At the ages of $7,14,21,28,35$ and 42 days, the live weight of poultry in the experimental groups tended to increase relative to control. 
The live weight of chickens at the beginning of the experiment was almost the same, but at 7 days of age it tended to increase in chickens of the experimental group, although a significant difference between groups in this indicator was not found. Indicators of live weight of broiler chickens of the experimental groups are presented in Table 2.

Live weight of chickens of the experimental group at the age of 7, 14,21, 28, 35 and 42 days prevailed over broilers of the control group, respectively, by $1.1 \mathrm{~g} ; 22.1 \mathrm{~g}(p<0.01) ; 35.4 \mathrm{~g}(p<0.01)$; $94.5 \mathrm{~g}(p<0.05) ; 133.6 \mathrm{~g}(p<0.01) ; 218.9 \mathrm{~g}(p<0.05)$.

During the experiment, disorders of the gastrointestinal tract in broiler chickens of the experimental group were not detected. Indicators for determining the safety of chickens in the control and experimental groups are given in Table $\mathbf{3}$.

Table 2

Dynamics of live weight of broiler chickens, $\mathrm{g}(M \pm m, n=50)$

\begin{tabular}{|c|c|c|}
\hline \multirow{2}{*}{ Age of broilers, days } & \multicolumn{2}{|c|}{ Groups } \\
\hline & control & study \\
\hline 1 & $40.3 \pm 0.5$ & $40.4 \pm 0.4$ \\
\hline 7 & $118.2 \pm 1.1$ & $119.3 \pm 1.4$ \\
\hline 14 & $333.3 \pm 3.2$ & $355.4 \pm 3.9^{* *}$ \\
\hline 21 & $791.2 \pm 5.6$ & $826.6 \pm 8.3 * *$ \\
\hline 28 & $1265.0 \pm 31.2$ & $1359.5 \pm 15.8^{*}$ \\
\hline 35 & $1799.9 \pm 22.7$ & $1933.5 \pm 31.7 * *$ \\
\hline 42 & $2435.4 \pm 48.2$ & $2654.3 \pm 63.2^{*}$ \\
\hline
\end{tabular}

Note: ${ }^{*} p<0.05 ;{ }^{* *} p<0.01 ;{ }^{* * *} p<0.001$ compared with the control group

Table 3

Survival rate of broiler chickens

\begin{tabular}{ccc}
\hline Indicator & \multicolumn{2}{c}{ Groups } \\
\cline { 2 - 3 } & control & study \\
\hline Number of broilers & 50 & 50 \\
Died of broilers & 4 & 2 \\
Survival, \% & 92.0 & 96.0
\end{tabular}

According to Table 3, at the beginning of the experiment in the control and experimental groups were 50 chickens. At the end of the experiment, their number was smaller and amounted to 46 ones in the control group, 48 broilers in the experimental group. Accordingly, the survival rate was 92 and $96 \%$.

It was found that the growth intensity of young animals depended on the consumption of feed with sulfate and the chelated form of Zinc, which affected the cost of feed per $1 \mathrm{~kg}$ of weight gain. The results are presented in Table 4.

When raising chickens at all ages, feed costs per unit live weight gain were lower in broilers, which was fed compound feed with the addition of chelated forms of Zinc. Thus, this indicator was the lowest in the young of the experimental group, but no statistical difference was found in the statistical processing. By age, feed costs per unit weight gain were lower in the experiment, respectively: $0.05 ; 0.08 ; 0.12 ; 0.06 ; 0.07$ and $0.05 \mathrm{~kg}$, compared to the control group.

The next stage of the research was to determine the slaughter quality of carcasses of broilers (Table 5). 
Table 4

Feed costs per $1 \mathrm{~kg}$ of live weight gain of broiler chickens, $\mathrm{kg}(n=50)$

\begin{tabular}{ccc}
\hline \multirow{2}{*}{ Age of broilers, days } & \multicolumn{2}{c}{ Groups } \\
\cline { 2 - 3 } & control & study \\
\hline $1-7$ & 2.01 & 2.96 \\
$8-14$ & 2.10 & 2.02 \\
$15-21$ & 2.46 & 2.04 \\
$22-28$ & 2.10 & 1.71 \\
$28-35$ & 1.78 & 1.78
\end{tabular}

The highest pre-slaughter live weight $(2649.3 \mathrm{~g})$ was in broiler chickens in the experimental group by $8.7 \%$ compared to the control $(p<0.01)$.

The weight of no non-eviscerated, semi-eviscerated and eviscerated carcasses in poultry of the experimental group was greater than similar indicators in the young broilers of the control group by $9.3,9.2$, and $9.8 \%$, and this difference was significant $(p<0.01)$.

The yield of semi-eviscerated carcasses was higher in broiler chickens of the experimental group $(84.19 \%)$, and the difference was significant $(p<0.05)$.

The results of slaughter of chickens of the experimental groups are presented in Table 5.

Table 5

Slaughter qualities of broiler carcasses $(M \pm m, n=3), \mathrm{g}$

\begin{tabular}{ccc}
\hline Indicators & \multicolumn{2}{c}{ Groups } \\
\cline { 2 - 3 } & control & study \\
\hline pre-slaughter mass & $2437.3 \pm 28.9$ & $2649.3 \pm 28.6^{* *}$ \\
weight of non-eviscerated carcass & $2223.3 \pm 18.5$ & $2429.6 \pm 26.2^{* *}$ \\
weight of semi-eviscerated carcass & $2041.7 \pm 24.3$ & $2230.3 \pm 22.9^{* *}$ \\
weight of eviscerated carcass & $1857.0 \pm 24.1$ & $2038.3 \pm 25.2^{* *}$ \\
weight of edible parts: & & $496.00 \pm 9.1^{*}$ \\
chest muscles & $445.0 \pm 6.5$ & $443.3 \pm 7.2^{*}$ \\
leg muscles & $399.7 \pm 6.1$ & $156.0 \pm 5.1$ \\
skin & $144.7 \pm 1.4$ & $45.3 \pm 2.2$ \\
internal fat & $40.3 \pm 1.4$ & $45.3 \pm 1.8$ \\
liver & $42.0 \pm 1.7$ & $15.3 \pm 0.3$ \\
lungs & $13.3 \pm 0.7$ & $9.7 \pm 0.3$ \\
kidneys & $9.3 \pm 0.3$ & $55.0 \pm 1.5$ \\
gizzard & $52.7 \pm 1.2$ & $13.3 \pm 0.3^{*}$
\end{tabular}

Note: ${ }^{*} p<0.05 ;{ }^{* *} p<0.01 ;{ }^{* * *} p<0.001$ compared with the control group

In the chickens of the experimental group there was a tendency to increase the yield of pectoral muscles, limb muscles, skin, lungs and heart, but a significant difference in these indi- 
cators in the birds of the control and experimental groups was not found, except for the output of the heart. The results of slaughter products of chickens of the experimental groups are presented in Table 6.

Table 6

Yield of slaughter products of broiler chickens, $\%(M \pm m, n=3), \mathrm{g}$

\begin{tabular}{ccc}
\hline Indicator & Groups \\
\cline { 2 - 3 } Yield of semi-eviscerated carcass & control & study \\
Yield of eviscerated carcass & $83.7 \pm 0.1$ & $74.2 \pm 0.1^{*}$ \\
Yield of edible parts: & $76.2 \pm 0.3$ & $76.9 \pm 0.3$ \\
chest muscles & & $18.7 \pm 0.2$ \\
leg muscles & $18.3 \pm 0.1$ & $16.7 \pm 0.1$ \\
skin & $16.4 \pm 0.1$ & $5.9 \pm 0.2$ \\
internal fat & $5.9 \pm 0.1$ & $1.7 \pm 0.1$ \\
liver & $1.6 \pm 0.1$ & $1.7 \pm 0.1$ \\
lungs & $1.7 \pm 0.1$ & $0.6 \pm 0.1$ \\
kidneys & $0.5 \pm 0.1$ & $0.4 \pm 0.1$ \\
gizzard & $0.4 \pm 0.1$ & $2.1 \pm 0.1$ \\
heart & $2.2 \pm 0.1$ & $0.6 \pm 0.1^{*}$
\end{tabular}

Note: ${ }^{*} p<0.05 ;{ }^{* *} p<0.01 ;{ }^{* * *} p<0.001$ compared with the control group

According to the results of the research, feeding broilers with chelated form of Zinc increases the pre-slaughter weight by $8.6 \%$ and the yield of edible parts of the carcasses.

\section{Discussion}

Pre-slaughter veterinary examination of broilers showed that no significant difference was found between the control and experimental groups. The bird of all groups behaved naturally: it reacted quite quickly and clearly to external stimuli, moved actively, with clear, elastic movements. Feed and water consumption - active without restrictions. The position of the body at rest and in motion is natural. The position of their body and head was natural both at rest and during movement, the feather cover is clean, dry, close to the body, visible mucous membranes of pale pink color, leaks from the eyes were not detected, the beak is dry, the ridges are pale pink, the surfaces of the extremities are dry, without damage and swelling, breathing without wheezing, body temperature ranged from 41 to $42^{\circ} \mathrm{C}$.

Thus, at the time of slaughter, the birds of the control and experimental groups were clinically healthy [22].

Zinc enters the body of animals with food or in the form of additives of inorganic compounds such as sulfate, carbonate or acetate. Trace elements in the form of salts of sulfates, chlorides and other inorganic compounds are absorbed in the body of animals by $5-30 \%$, and the remaining $70-95 \%$ are excreted from the body and pollute the environment [23].

In the cells of the animal body, Zinc, in the vast majority, is part of stable biocomplexes in which it is associated with endogenous organic ligands. This is due to the high ability of this trace element to form chelated compounds. The main feature is that for the formation of Zinc biocomplexes is relatively safe for biomolecules [24].

Studies have shown that the replacement of zinc from an inorganic compound to an organic one in the first experiment was accompanied by a probable increase in live weight of broiler chickens. 
The obtained results are in agreement with the data of other authors who conducted studies on broilers [2, 24] and which also indicate the positive effect of the introduction of different doses of organic zinc compounds on live weight of poultry.

Study limitations. A limitation of the research is the insufficient number of animals involved in the experiment, for a more accurate statistical calculation of the results.

Prospects for further research. The prospect of further research is to determine the effect of feeding chelated forms of zinc on broiler chickens in industrial conditions.

\section{Conclusions}

It was found that the live weight of chickens of the experimental group (consumption of feed with chelated form of Zinc) at the age of 7, 14, 21, 28, 35 and 42 days prevailed over broilers of the control group (consumption of feed with zinc sulfate), respectively, by $1.1 \mathrm{~g} ; 22.1 \mathrm{~g}(p<0.01)$; $35.4 \mathrm{~g}(p<0.01)$; $94.5 \mathrm{~g}(p<0.05) ; 133.6 \mathrm{~g}(p<0.01) ; 218.9 \mathrm{~g}(p<0.05)$.

Preservation of young animals in the experimental group, which used chelated compounds of Zinc, was higher and amounted to $96 \%$, compared with the control - $92 \%$.

By age, feed costs per unit weight gain were lower in the study group, respectively: 0.05 ; $0.08 ; 0.12 ; 0.06 ; 0.07$ and $0.05 \mathrm{~kg}$, compared to the control group.

Growing broiler chickens on compound feed with a chelated form of Zinc by $9.8 \%(p<0.01)$ increases the weight of the eviscerated carcass.

\section{Conflict of interests}

The authors declare there is no conflict of interests.

\section{Financing}

The research is part of the research work of the Department Of Veterinary Examination, Microbiology, Zoohygiene And Safety And Quality Of Livestock Products of Sumy NAU on «Development and improvement of veterinary and sanitary measures to prevent, treat, increase productivity and resistance of animals» (state registration number1 011910).

\section{References}

[1] Alkhtib, A., Scholey, D., Carter, N., Cave, G. W. V., Hanafy, B. I., Kempster, S. R. J. et. al. (2020). Bioavailability of Methionine-Coated Zinc Nanoparticles as a Dietary Supplement Leads to Improved Performance and Bone Strength in Broiler Chicken Production. Animals, 10 (9), 1482. doi: http://doi.org/10.3390/ani10091482

[2] Hussan, F., Krishna, D., Preetam, V. C., Reddy, P. B., Gurram, S. (2021). Dietary Supplementation of Nano Zinc Oxide on Performance, Carcass, Serum and Meat Quality Parameters of Commercial Broilers. Biological Trace Element Research. doi: http://doi.org/10.1007/s12011-021-02635-Z

[3] Gomathi, G., Senthilkumar, S., Natarajan, A., Amutha, R., Purushothaman, M. R. (2018). Effect of dietary supplementation of cinnamon oil and sodium butyrate on carcass characteristics and meat quality of broiler chicken. Veterinary World, 11 (7), 959-964. doi: http://doi.org/10.14202/vetworld.2018.959-964

[4] Olukosi, O. A., van Kuijk, S., Han, Y. (2018). Copper and zinc sources and levels of zinc inclusion influence growth performance, tissue trace mineral content, and carcass yield of broiler chickens. Poultry Science, 97 (11), 3891-3898. doi: http://doi.org/ $10.3382 / \mathrm{ps} /$ pey 247

[5] Sunder, G. S., Panda, A. K., Gopinath, N. C. S., Rao, S. V. R., Raju, M. V. L. N., Reddy, M. R., Kumar, C. V. (2008). Effects of Higher Levels of Zinc Supplementation on Performance, Mineral Availability, and Immune Competence in Broiler Chickens. Journal of Applied Poultry Research, 17 (1), 79-86. doi: http://doi.org/10.3382/japr.2007-00029

[6] Timoshenko, R. Y., Fotina, T. I., Nazarenko, S. M. (2019). Veterinary-sanitary evaluation of broiler chickens' meat after adding chelated trace elements to their diet. Bulletin «Veterinary Biotechnology», 34, 154-160. doi: http://doi.org/10.31073/ vet_biotech34-19

[7] Yatsenko, I. V., Bohatko, N. M., Bukalova, N. V., Biben, I. A., Fotina, T. I., Busol, L. V. et. al. (2019). Hihiiena i ekspertyza produktiv pervynnoi pererobky zabiinykh tvaryn. Nova ideolohiia, 1200.

[8] Jarosz, Ł., Marek, A., Grądzki, Z., Kwiecień, M., Kalinowski, M. (2017). The effect of feed supplementation with zinc chelate and zinc sulphate on selected humoral and cell-mediated immune parameters and cytokine concentration in broiler chickens. Research in Veterinary Science, 112, 59-65. doi: http://doi.org/10.1016/j.rvsc.2016.09.007 
[9] Singh, A. K., Ghosh, T. K., Haldar, S. (2015). Effects of Methionine Chelate- or Yeast Proteinate-Based Supplement of Copper, Iron, Manganese and Zinc on Broiler Growth Performance, Their Distribution in the Tibia and Excretion into the Environment. Biological Trace Element Research, 164 (2), 253-260. doi: http://doi.org/10.1007/s12011-014-0222-2

[10] Mondal, S., Haldar, S., Saha, P., Ghosh, T. K. (2009). Metabolism and tissue distribution of trace elements in broiler chickens' fed diets containing deficient and plethoric levels of copper, manganese, and zinc. Biological Trace Element Research, 137 (2), 190-205. doi: http://doi.org/10.1007/s12011-009-8570-Z

[11] Bao, Y. M., Choct, M., Iji, P. A., Bruerton, K. (2010). Trace mineral interactions in broiler chicken diets. British Poultry Science, 51 (1), 109-117. doi: http://doi.org/10.1080/00071660903571904

[12] Chand, N., Naz, S., Khan, A., Khan, S., Khan, R. U. (2014). Performance traits and immune response of broiler chicks treated with zinc and ascorbic acid supplementation during cyclic heat stress. International Journal of Biometeorology, 58 (10), 2153-2157. doi: http://doi.org/10.1007/s00484-014-0815-7

[13] Jahanian, R., Rasouli, E. (2015). Effects of dietary substitution of zinc-methionine for inorganic zinc sources on growth performance, tissue zinc accumulation and some blood parameters in broiler chicks. Journal of Animal Physiology and Animal Nutrition, 99 (1), 50-58. doi: http://doi.org/10.1111/jpn.12213

[14] Bao, Y. M., Choct, M., Iji, P. A., Bruerton, K. (2009). Optimal dietary inclusion of organically complexed zinc for broiler chickens. British Poultry Science, 50 (1), 95-102. doi: http://doi.org/10.1080/00071660802590377

[15] Aksu, T., Aksu, M. İ., Yoruk, M. A., Karaoglu, M. (2011). Effects of organically-complexed minerals on meat quality in chickens. British Poultry Science, 52 (5), 558-563. doi: http://doi.org/10.1080/00071668.2011.606800

[16] Dai, S. F., Gao, F., Xu, X. L., Zhang, W. H., Song, S. X., Zhou, G. H. (2012). Effects of dietary glutamine and gamma-aminobutyric acid on meat colour, $\mathrm{pH}$, composition, and water-holding characteristic in broilers under cyclic heat stress. British Poultry Science, 53 (4), 471-481. doi: http://doi.org/10.1080/00071668.2012.719148

[17] Da Costa, M. J., Oviedo-Rondón, E. O., Wineland, M. J., Claassen, K., Osborne, J. (2016). Effects of incubation temperatures and trace mineral sources on chicken live performance and footpad skin development. Poultry Science, 95 (4), $749-759$. doi: http://doi.org/10.3382/ps/pev446

[18] Vieira, R., Ferket, P., Malheiros, R., Hannas, M., Crivellari, R., Moraes, V., Elliott, S. (2020). Feeding low dietary levels of organic trace minerals improves broiler performance and reduces excretion of minerals in litter. British Poultry Science, 61 (5), 574-582. doi: http://doi.org/10.1080/00071668.2020.1764908

[19] Bhagwat, V. G., Balamurugan, E., Rangesh, P. (2021). Cocktail of chelated minerals and phytogenic feed additives in the poultry industry: A review. February-2021, 14 (2), 364-371. doi: http://doi.org/10.14202/vetworld.2021.364-371

[20] Hassan, S., Hassan, F., Rehman, M. S. (2019). Nano-particles of Trace Minerals in Poultry Nutrition: Potential Applications and Future Prospects. Biological Trace Element Research, 195 (2), 591-612. doi: http://doi.org/10.1007/s12011-019-01862-9

[21] Zhu, Z., Yan, L., Hu, S., An, S., Lv, Z., Wang, Z. et. al. (2019). Effects of the different levels of dietary trace elements from organic or inorganic sources on growth performance, carcass traits, meat quality, and faecal mineral excretion of broilers. Archives of Animal Nutrition, 73 (4), 324-337. doi: http://doi.org/10.1080/1745039x.2019.1620050

[22] Van Kuijk, S. J. A., Han, Y., Garcia-Ruiz, A. I., Rodiles, A. (2021). Hydroxychloride trace minerals have a positive effect on growth performance, carcass quality and impact ileal and cecal microbiota in broiler chickens. Journal of Animal Science and Biotechnology, 12 (1). doi: http://doi.org/10.1186/s40104-021-00553-7

[23] Santos, T. S. dos, Augusto, K. V. Z., Han, Y., Sartori, M. M. P., Denadai, J. C., Santos, C. T. et. al. (2021). High levels of copper and zinc supplementation in broiler diets on growth performance, carcase traits and apparent ileal mineral absorption. British Poultry Science, 1-10. doi: http://doi.org/10.1080/00071668.2021.1887453

[24] Salim, H. M., Lee, H. R., Jo, C., Lee, S. K., Lee, B. D. (2011). Effect of Sex and Dietary Organic Zinc on Growth Performance, Carcass Traits, Tissue Mineral Content, and Blood Parameters of Broiler Chickens. Biological Trace Element Research, 147 (1-3), 120-129. doi: http://doi.org/10.1007/s12011-011-9282-8

Received date 02.03.2021

(C) The Author(s) 2021

Accepted date 06.05.2021

This is an open access article

Published date 25.05.2021

under the Creative Commons CC BY license

How to cite: Fotina, T., Fotina, H., Nazarenko, S., Tymoshenko, R. Fotin, O. (2021). Effect of feeding of chelated zinc form on security, productivity and slaughter parameters of broilers. EUREKA: Health Sciences, 3, 110-118. doi: http://doi.org/10.21303/ 2504-5679.2021.001856 